\title{
In vitro effect of the gonad of Helix aspersa (Mollusca) on galactogen synthesis in the albumen gland of either mated or virgin snails
}

\author{
J Bride, L Gomot \\ Laboratoire de zoologie et embryologie, UFR sciences et techniques, place du Maréchal-Leclerc, \\ 25030 Besançon cedex, France
}

(Received 26 September 1994; accepted 7 July 1995)

\begin{abstract}
Summary - The gonad of Helix aspersa contains a factor which can stimulate in a dose-dependent manner galactogen synthesis in albumen gland explants cultured in vitro. The stimulatory activity appears to be greater when the gonad is predominantly male than when it is predominantly female. The albumen gland of virgin snails does not respond in vitro to the gonadal influence. The receptivity of the albumen gland to the galactogen synthesis stimulating effect of the gonad is increased after the first and second mating. It decreases at the third mating in correlation with the increase of the albumen gland maturation index.
\end{abstract}

Helix aspersa / albumen gland / galactogen / gonad / mating

Résumé - Effet in vitro de la gonade de Helix aspersa sur la synthèse de galactogène de la glande à albumen d'escargots vierges ou accouplés. La gonade de Helix aspersa contient un facteur capable de stimuler, d'une façon dépendante de la dose, la synthèse de galactogène dans des explants de glande à albumen cultivés in vitro. L'activité stimulante apparaît plus importante dans la gonade en phase mâle dominante que dans la gonade en phase femelle dominante. La glande à albumen d'escargots vierges ne répond pas à l'influence gonadique in vitro. La réceptivité de la glande à albumen à l'effet stimulant de la gonade sur la synthèse de galactogène est augmentée après le premier et le deuxième accouplement. Elle diminue au troisième accouplement corrélativement à l'augmentation de lindice de maturation glandulaire.

Helix aspersa / glande à albumen / galactogène / gonade / accouplement 


\section{INTRODUCTION}

In pulmonate molluscs, the albumen gland, one of the female accessory sex organs, secretes perivitelline fluid around the fertilized eggs (May, 1934). This fluid's primary constituent is galactogen (Goudsmit and Ashwell, 1965) which provides the main energy source for the developing embryo (Horstmann, 1965; Goudsmit, 1976). Growth and differentiation of the albumen gland in stylommatophoran snails and slugs are under the endocrine control of both the gonad (Abeloos, 1943; Laviolette, 1954; Sokolove et al, 1986) and the dorsal bodies (Wijdenes and Runham, 1976). With regard to the synthetic activity of the albumen gland, in vitro experiments demonstrated a direct endocrine control by factors produced either in the central nervous system (Goudsmit, 1975, 1978) or in the nonnervous dorsal bodies (Van Minnen and Sokolove, 1984).

In Helix aspersa, the direct stimulation of organites implicated in the albumen gland secretion by the gonad was demonstrated using an ultrastructural study of organ associations cultured on a semi-solid medium (Gomot and Courtot, 1979). Castrations and gonadal implantations indicated that in addition to growth and differentiation, galactogen synthesis in the albumen gland is stimulated by implantation of gonads removed from active snails. In addition, it was shown that implantation of gonads from hibernating snails caused an increase of albumen gland glycogen secretion whereas gonads from active snails caused a stimulation of galactogen synthesis (Berset de Vaufleury et al, 1986). Therefore, it appears that the physiological state of implanted gonads interferes with experimental results.

The aim of the present in vitro study in $\mathrm{H}$ aspersa was, first, to investigate a liquid medium assay in which the determination of the galactogen synthesis by incorporation of
${ }^{14} \mathrm{C}$-glucose would be easier than ultrastructural observations. Secondly, this study was undertaken to check whether the gonadal effect demonstrated ultrastructurally in some organites of cultured albumen glands (Gomot and Courtot, 1979) corresponds to the stimulation of the galactogen synthesis and whether variations of this effect are correlated to physiological stages of the sexual cycle. Investigations were made in both virgin and mated snails.

\section{MATERIALS AND METHODS}

\section{Animals}

One-month-old sexually immature snails were raised individually in $500 \mathrm{ml}$ plastic containers under constant temperature $\left(20^{\circ} \mathrm{C}\right)$, photoperiod $(18 \mathrm{~h} \mathrm{~L}, 6 \mathrm{~h} \mathrm{D})$ and relative humidity $(95 \%)$. They were fed powdered food (UCAAB, Chierry, 02400 Château-Thierry, France) ad libitum once a day. These snails attained adult size and became sexually mature at 4 months, coincident with the upturning of the shell edge. Similarly, one-monthold snails were raised in groups of 10 in $2000 \mathrm{ml}$ plastic containers under the same conditions.

A glass jar filled with moist soil was provided for egg laying. Each snail was numbered with adhesive tape. The reproductive activity (copulations, egg laying) was carefully monitored (once in the morning, once in the evening). This allowed us to know exactly the reproductive stage of each animal. In this way, it was possible to choose pairs of snails to study the effect of either single or repeated mating on the in vitro response of the albumen gland galactogen synthesis to the gonadal extracts.

In H aspersa, egg laying is generally preceded by multiple mating as it is reported in other species (Van Duivenboden and Ter Maat, 1985; Baur, 1988; Khan et al, 1990). Several data demonstrated the importance of mating as a stimulant of the female sexual activity as compared to virgin snails (Van Duivenboden, 1983; Saleuddin et al, 1983, 1989; Khan et al, 1990; Saleuddin et al, 1991). 


\section{Tissue preparation}

The albumen gland was removed from virgin, single-mated or repeatedly mated snails. After the animal had been weighed, the albumen gland was removed and its maturation index $(\mathrm{mi})$ was calculated:

$$
\mathrm{mi}=\frac{\text { wt of albumen gland }}{\text { wt of animal }} \times 100
$$

Explants of albumen gland were then prepared as previously described (Bride et al, 1991). Five samples were used for control conditions and groups of 5 other samples for experimental conditions.

The gonads were cleanly separated, teased away from the underlying hepatopancreas with fine forceps and then rinsed in a saline solution (McCrone and Sokolove, 1979). Each gonad was homogenized in a minimal volume $(50 \mu \mathrm{l})$ of $0.1 \mathrm{M}$ Hepes buffer, $\mathrm{pH} 7.4$, then centrifuged at $12000 \mathrm{~g}$ for $10 \mathrm{~min}$ at $4^{\circ} \mathrm{C}$. The supernatant contained the gonadal extract of one animal equivalent (1 ae).

For the study of the dose-response relationship, gonads were removed from a population of adult reproductively active $H$ aspersa in the dominant male phase after egg-laying. The supernatants were gathered together in a pool (R). Pooled gonads were also removed from 4-monthold virgin snails $(V)$.

In paired snails, gonads and albumen glands were removed within $6 \mathrm{~h}$ after copulation and immediately prepared for culture. The stage of differentiation of the gonads was estimated by careful examination under a microscope. In $H$ aspersa, the ovotestis first shows a male phase and contains mainly spermatozoa. This stage is gradually replaced by a phase of oogenesis including a primary vitellogenic stage characterized by small oocytes and a secondary vitellogenic stage containing large oocytes.

Each gonad of mated snails was individually homogenized and the supernatant was divided in 2 parts of 0.5 ae. Thus, in each pair, a 0.5 ae of gonadal extract of one of the partners was added to autologous albumen gland explants and the other 0.5 ae to the explants from the second partner and vice versa (see fig 2 below).

\section{Culture medium}

The liquid medium containing ${ }^{14} \mathrm{C}$-glucose as precursor for galactogen synthesis was prepared as previously described (Bride et al, 1991). The culture time was $24 \mathrm{~h}$ at room temperature in the dark.

\section{Determination of the galactogen synthesis}

The galactogen synthesis was determined by measuring the incorporation of ${ }^{14} \mathrm{C}$-glucose as previously described (Bride et al, 1991).

\section{Statistical analysis}

The results were statistically tested in a one-way analysis of variance followed by the multiple range test of Newman and Keul (Zar, 1978) at a probability level of 0.05 .

\section{RESULTS}

\section{Experiments in virgin snails}

\section{Effect of gonadal extracts on the albumen gland of virgin snails}

Five 4.5-month-old virgin snails were randomly chosen. The influence of the pooled gonadal extract of either reproductively active snails $(R)$ or virgin snails $(V)$ was investigated on the in vitro incorporation of ${ }^{14} \mathrm{C}$-glucose in galactogen synthesized by explants of the albumen glands. Galactogen was synthesized by individual albumen glands at different basal rates as reported in Goudsmit (1978) and Van Minnen et al (1983). ${ }^{14} \mathrm{C}$-Glucose incorporation in the presence of $R$ or $V$ did not vary significantly from the control basal synthetic activity (table I). Thus, the albumen glands of 4.5-month- 
Table I. Effect of gonadal extracts on galactogen synthesis in albumen glands from virgin snails.

Albumen gland mi

${ }^{14} \mathrm{C}$-Glucose incorporation ( $d p m / m g$ wet weight; $m \pm S D$ )

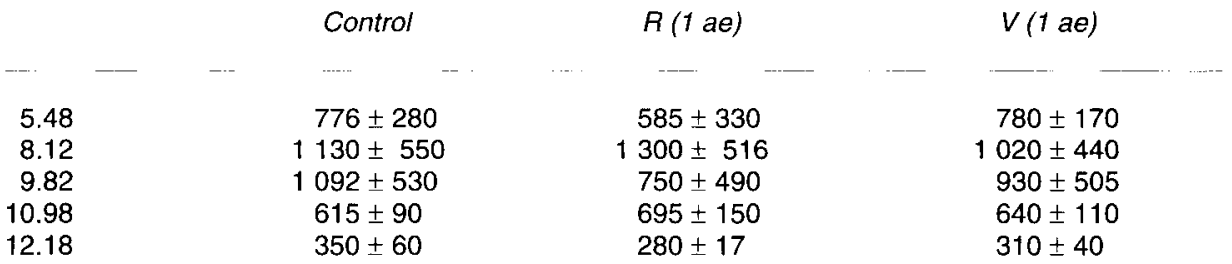

In vitro glucose incorporation in newly synthesized galactogen in albumen gland explants from virgin snails in the presence of 1 ae (animal equivalent, see Materials and methods) of gonadal extract from either reproductively active snails $(\mathrm{R})$ in dominant male phase after egg-laying or virgin snails $(\mathrm{V}) . n=5$; mi: maturation index (see Materials and methods).

old virgin snails are not responsive to gonadal influence in vitro.

\section{Demonstration of the galactogen syn- thesis stimulatory activity of the gonad of virgin snails}

The pooled extract of gonads of virgin snails (V) added to explants of albumen gland from a reproductively active snail in the male phase after egg-laying ( $\mathrm{mi}=3.3$ ) caused a significant increase of galactogen synthesis by $88 \%$ for 1 ae as compared to the control (fig 1).

\section{Experiments in mated snails}

\section{Effect of gonads of reciprocally mated snails tested on their own albu- men gland synthesis}

Because a difference in the level of response of the albumen gland was found between the first-mated and the repeatedly mated snails, in our experiments we selected snails for which copulation occurred for the first time for snail 1 and for the second time without egg-laying for snail 2 (fig 2).
The albumen gland of single-mated snail 1 was characterized by a mi of 3.05 whereas that of twice-mated snail 2 is larger $(\mathrm{mi}=8.36)$. The galactogen synthesis in control medium was also different between the partners. In twice-mated snail 2 , the basal synthesis was $53 \%$ significantly lower than control 1 . Nevertheless, the albumen gland of the repeatedly mated

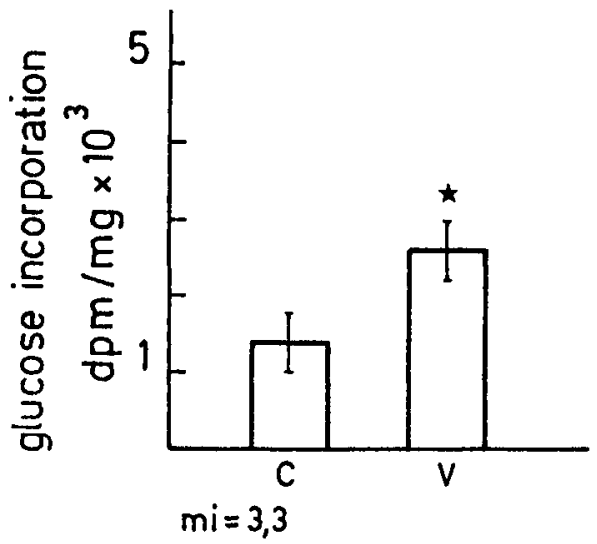

Fig 1. Effect of gonadal extract from virgin snails (V) on galactogen synthesis of the albumen gland from a mature snail after egg-laying. The star indicates a significant stimulation. Mean $\pm \mathrm{SD}$ $(n=5), p<0.05 . C=$ control (albumen gland without gonadal extract). 
Fig 2. Galactogen synthesis by albumen gland of snails mated once (1) and twice (2). Effect of 0.5 ae of gonadal extract from male (1) or female (2) phase gonads. Mean $\pm \mathrm{SD}(n=5), p<0.05$.

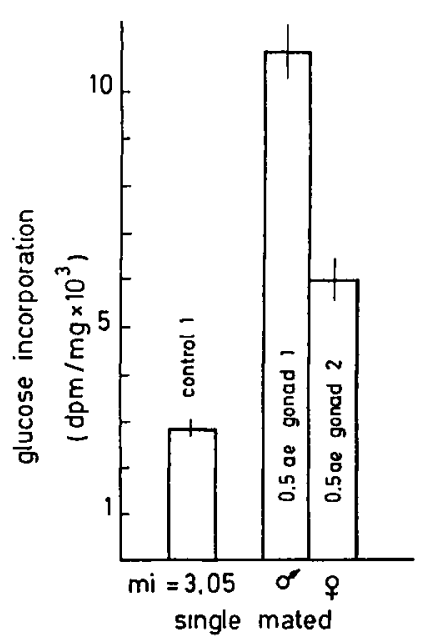

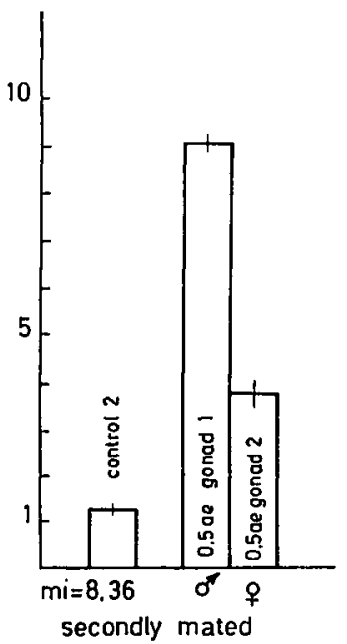

snail 2 was more responsive to the 0.5 ae of gonadal extracts than that of singlemated snail 1. Indeed, 0.5 ae of the male phase gonad of snail 1 caused an increase of galactogen synthesis in albumen gland from snail 2 of $610 \%$ compared with control 2 and only of $280 \%$ in albumen gland from snail 1 as compared with control 1 . The gonad from twice mated snail 2 in the first vitellogenic female stage was less active than the male gonad of the single-mated snail 1. The gonad from snail 2 (0.5 ae) increased galactogen synthesis by only $110 \%$ compared control 1 and $183 \%$ compared with control 2.

In another experiment the pair consisted of snail 3 (which copulated for the first time in the second cycle of matings and egg-laying, after emptying its albumen gland and gonad by egg-laying) and snail 4 which cop-
Fig 3. Dose-response relationship of galactogen synthesis stimulation in albumen gland from a mated snail by gonadal pooled saline extract of reproductively active snails in the dominant male phase. Each point represents mean \pm SD of 5 explants and those sharing a common letter do not differ significantly $(p<0.05)$.

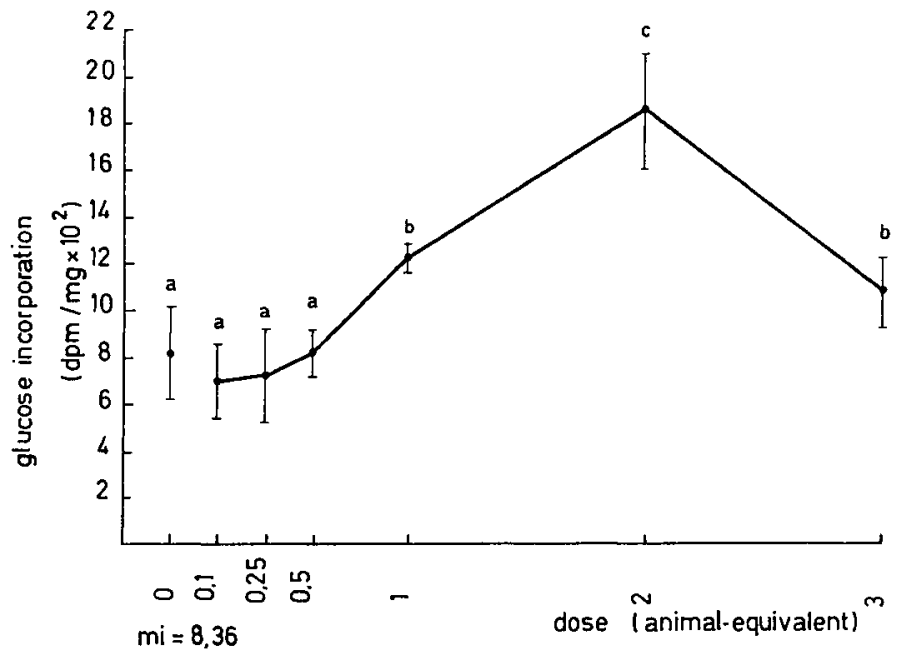


ulated for the third time in its first cycle without having laid eggs.

Albumen gland $\mathrm{mi}$ of the partners were different: 4.65 for the first-mated snail 3 in male phase, and 11.2 for the repeatedly mated snail 4 in second vitellogenic female phase. The basal activity (control 4) of the large albumen gland from snail 4 was significantly 3 times lower $(p<0.01)$ than that from snail 3 (control 3 ). Only the minute gland from the first-mated snail 3 was stimulated by the 0.5 ae of its male phase gonad (3) which increased galactogen synthesis by $68 \%$. The large albumen gland from snail 4 , which was mated 3 times, did not respond to the stimulatory activity of the male gonad from snail $3(0.5 \mathrm{ae})$. The extract of the gonad from snail 4 , in second vitellogenic stage of the female phase, did not significantly stimulate the sensitive albumen gland from snail 3 or the large albumen gland from snail 4 .

\section{Dose-response relationship of the effect of pooled gonadal extract on in vitro galactogen synthesis}

The influence of aliquots of gonadal extract $R$ on the galactogen synthesis of the albumen gland $(\mathrm{mi}=8.6)$ removed the day after the first mating was demonstrated (fig 3 ). The minimum dose to elicit a significant stimulation over the control is 1 ae which increased the ${ }^{14} \mathrm{C}$-glucose incorporation by $50 \%$ compared with the control. The dose to obtain a maximum response was 2 ae which caused a rise of galactogen synthesis by $102 \%$ compared with the control.

\section{DISCUSSION AND CONCLUSION}

A point illustrated by this study is that the gonad of adult active $H$ aspersa appears to contain a factor which exerts a direct stimulatory activity on galactogen synthesis of albumen glands in the appropriate stage of the sexual cycle.

The above in vitro results do not agree with observations in basommatophorans where castration experiments have indicated that neither the development nor the activity of the accessory sex organs is under endocrine control of the gonad (Brisson, 1971; De Jong-Brink et al, 1979; VianeyLiaud, 1979).

The results demonstrate that the level of in vitro stimulation of albumen gland synthetic activity by crude saline gonadal extracts depends on the receptivity of the albumen gland and on the differentiation stage of the gonad. These 2 parameters vary with the reproductive stages of the snails. Three stages of reproductive activity have been considered in $H$ aspersa, corresponding to virgin, single-mated and repeatedly mated animals.

\section{Albumen gland receptivity and reproductive stage of the snail}

The albumen gland from isolated virgin animal does not respond to the stimulatory activity of the gonadal extract. Two hypothesis may be proposed concerning this observation:

1) The receptors implied in the stimulatory activity of the gonadal extract are not activated, due to the lack of mating.

2) As it was demonstrated in Helisoma duryi (Miksys and Saleuddin, 1987), we have observed that the albumen glands of isolated virgin animals are more developed than in reproductive snails. A large amount of secretion stored in the albumen gland may explain the lack of galactogen synthesis stimulation we observed. This has been previously described in Lymnaea stagnalis (Wijdenes et al, 1981), Limax maximus (Van Minnen et al, 1983) and $H$ duryi (Miksys and Saleuddin, 1985), where a large quantity of secretory material in albumen gland may 
inhibit the responses to galactogen synthesis stimulating factors from parts of the brain.

After mating, there is a marked difference in the level of the stimulation observed in vitro between the albumen gland from single-mated and repeatedly mated snails. At the second mating, the in vitro stimulation of the albumen gland galactogen synthesis is higher than in snails mated either once or three times. The first and the second mating promote the receptivity of the albumen gland for the in vitro stimulation of galactogen synthesis by the gonadal extract. It can be extrapolated that the activation of the galactogen synthesis machinery would be caused by the transfer of sperm and male secretions from the partner (Van Duivenboden, 1983), which have a direct stimulatory effect on the albumen gland (Bride and Gomot, 1991b). At the third mating, the large albumen gland becomes unresponsive in vitro to the stimulatory activity of the gonadal extract. Moreover, its low basal synthetic activity (control value) suggests that the in vivo level of galactogen synthesis has also decreased. The absence of a significant effect of the gonadal extract on the synthetic activity of the large gland indicates that the storage of the secretory product arising from synthesis of galactogen after mating (Bride et al, 1991; Bride and Gomot, 1991a,b) may account for the lack of stimulation for further synthesis of galactogen. As observed in L stagnalis (Wijdenes et al, 1981) and $L$ maximus (Van Minnen et al, 1983), the quantitative response of the albumen gland of $H$ aspersa can change considerably with the weight of the gland, or mi, which varies in different stages of the sexual cycle.

\section{Relation between the stage of differentiation of the gonad and the effect of gonadal extract on galactogen synthesis}

The nature of the stimulatory gonadal factor is unknown. However, it appears that in vitro galactogen synthesis in albumen glands is more active in the presence of extract of male phase gonad in spermiogenesis (at the first mating) than under the influence of extract of vitellogenic female phase gonad (second and third mating). This difference of influence between predominantly male and predominantly female gonads was also demonstrated in the in vitro study of polysaccharide synthesis in the oviduct of $H$ aspersa (Bride and Gomot, 1988). The reason for these differences is not known. Nevertheless, they can be correlated with previous studies on implantation with male gonads in $H$ aspersa (Berset de Vaufleury et al, 1986) and in slugs (Laviolette, 1954) where implantation of gonads at the end of the spermiogenesis caused albumen gland and common duct enlargement whereas there was no response to implantation of gonads that had not begun spermiogenesis. In virgin $H$ aspersa, the gonads which elicit galactogen synthesis stimulating activity are full of spermatozoa and contain only previtellogenic oocytes. This was also observed in $H$ duryi, whose vitellogenesis was arrested in virgins because of the inactivity of the dorsal bodies (Saleuddin et al, 1983).

In conclusion, these results indicate the possibility of using this albumen gland bioassay to test the effect of fractions isolated by chemical extraction of the gonad. It also raises questions related to the cause of the evolution of albumen gland receptivity with respect to the role of repeated matings preceding egg-laying and the existence of a cycle in the production of gonadal endocrine factor(s) with respect to the correlation between: a) spermiogenesis and the presence of a gonadal galactogen synthesis stimulatory substance; and b) vitellogenesis and the disappearance of this galactogen synthesis stimulatory substance.

\section{ACKNOWLEDGMENTS}

We thank $\mathrm{C}$ Afonso and $\mathrm{C}$ Chitwood for typing the manuscript. 


\section{REFERENCES}

Abeloos M (1943) Effet de la castration chez un mollusque Limax maximums. CR Acad Sci Paris 216. 90-91

Baur B (1988) Repeated mating and female fecundity in the simultaneous hermaphroditic land snail Arianta arbustorum. Invertebr Reprod Dev 14, 197204

Berset de Vaufleury JP, Bride J, Gomot L (1986) Mise en évidence du rôle endocrine de la gonade dans le développement de l'appareil génital de l'escargot Helix aspersa. CR Soc Biol 180, 190-196

Bride J, Gomot $L$ (1988) The polysaccharide in vitro synthesis of the oviduct of Helix aspersa: a bioassay to observe the activity of the endocrine organs, the gonad and the cephalic neuroendocrine complex. CR Acad Sci Paris 307, 199-204

Bride J, Gomot L (1991a) Asynchronisme du développement du tractus génital de l'escargot Helix aspersa pendant la croissance et la reproduction. Reprod Nutr Dev 31, 91-96

Bride J, Gomot L (1991b) Mise en évidence in vitro de la stimulation directe de la synthèse de galactogène dans la glande à albumen d'Helix aspersa par les extraits des glandes accessoires mâles du tractus génital. CR Acad Sci Paris 313, 565-571

Bride J, Gomot L, Saleuddin ASM (1991) Mating and 20 hydroxyecdysone cause increased galactogen synthesis in the albumen gland explants of Helix aspersa (Mollusca). Comp Biochem Physiol 98 B, 369-373

Brisson $P$ (1971) Castration chirurgicale et régénération gonadique chez quelques planorbidés (gastéropodes pulmonés). Ann Embryol Morphogen $4,189-210$

De Jong-Brink M, Ter Borg JP, Bergamin-Sassen MJM, Boer HH (1979) Histology and histochemistry of the reproductive tract of the pulmonate snail Bulinus truncatus, with observations on the effect of castration on its growth and histology. Int $J$ Invertebr Reprod 1, 41-56

Gomot L, Courtot AM (1979) Étude en culture in vitro du contrôle endocrine de la glande à albumen chez l'escargot Helix aspersa. Malacologica 18, 361-367

Goudsmit EM (1975) Neurosecretory stimulation of galactogen synthesis within the Helix pomatia albumen gland during organ culture. J Exp Zool 191, 193-198

Goudsmit EM (1976) Galactogen catabolism by embryos of the frestiwater snails Bulimnaea megasoma and Lymnaea stagnalis. Comp Biochem Physiol $55 \mathrm{~B}$, 439-442

Goudsmit EM (1978) Calcium-dependent release of a neurochemical messenger from the brain of the land snail, Helix pomatia. Brain Res 151, 418-423
Goudsmit E, Ashwell G (1965) Enzymatic synthesis of galactogen in the snail Helix pomatia. Biochem Biophys Res Comm 19, 417-422

Horstmann HJ (1965) Studies on galactogen metabolism in Helix pomatia. III. Analysis of galactogen in young animals. Z Biol 115, 133-155

Khan HR, Ashton ML, Saleuddin ASM (1990) Changes in the fine structure of the endocrine dorsal body cells of Helisomia duryi (Mollusca) induced by mating. J Morphol 203, 41-53

Laviolette $P$ (1954) Rôle de la gonade dans le déterminisme humoral de la maturité glandulaire du tractus génital chez quelques gastéropodes Arionidae et Limacidae. Bull Biol Fr Belg 88, 310-332

May F (1934) Galaktogen and glykogengehalt bel hungernden Weinbergschnecken. Z Biol 95, 606613

McCrone EJ, Sokolove PG (1979) Brain gonad axis and photoperiodically stimulated sexual maturation in the slug Limax maximus. J Comp Physiol 133, 117123

Miksys SL, Saleuddin ASM (1985) The effect of the brain and dorsal bodies of Helisoma duryi (Mollusca pulmonata) on albumen gland synthetic activity in vitro. Gen Comp Endocrinol 60, 419-426

Miksys SL, Saleuddin ASM (1987) Effects of castration on growth and reproduction of Helisoma duryi (Mollusca pulmonata). Int $J$ Invertebr Reprod Dev 12 , 145-160

Saleuddin ASM, Kunigelis SC, Schollen LM, Breckenridge WR, Miksys SL (1983) Studies on endocrine control of reproduction in Helisoma and Helix. In: Molluscan Neuroendocrinology (J Lever, H Boer, eds), North-Holland Publishing Co, Amsterdam, The Netherlands, 138-142

Saleuddin ASM, Ashton ML, Khan HR (1989) Matinginduced release of granules by the endocrine dorsal body cells in the snail Helisoma duryi (Mollusca). J Exp Zool 25, 206-216

Saleuddin ASM, Griffond B, Ashton ML (1991) An ultrastructural study of the activation of the endocrine dorsal bodies in the snail Helix aspersa by mating. Can J Zool 69, 1203-1215

Sokolove PG, McCrone EJ, Albert GR (1986) Role of brain and gonadal hormones in slug reproductive development: a reexamination. In: Neurobiology, Molluscan Models (AH Boer, WPM Geraerts, J Joosse, eds), North-Holland Publishing Co, Amsterdam, The Netherlands, 350-356

Van Duivenboden YA (1983) Transfer of semen accelerates the onset of egg-laying in female copulants of the hermaphrodite freshwater snail Lymnae stagnalis. Int J Invertebr Reprod 6, 249-257

Van Duivenboden YA, Ter Maat A (1985) Masculinity and receptivity in the hermaphrodite pond snail $\mathrm{Lym}$ nae stagnaliss. Anim Behav 33, 885-891 
Van Minnen J, Sokolove PG (1984) Galactogen synthesis stimulating factor in the slug, Limax maximus: cellular localization and partial purification. Gen Comp Endocrinol 54, 114-122

Van Minnen J, Wijdenes J, Sokolove PG (1983) Endocrine control of galactogen synthesis in the albumen gland of the slug Limax maximus. Gen Comp Endocrinol 49, 307-314

Vianey-Liaud M (1979) Effects of surgical castration on the growth on genital apparatus of the freshwater snail Biomphalaria glabrata (Gastropoda pulmonata). Experientia 35, 188-190
Wijdenes J, Runham NW (1976) Studies on the function of the dorsal bodies of Agriolimax reticulatus (Mollusca; pulmonata). Gen Comp Endocrinol 29, 545-557

Wijdenes J, Van Elk R, Joosse J (1981) Effects of 2 gonadotropic hormones on polysaccharide synthesis in the albumen gland of Lymnaea stagnalis, studied with the organ culture technique. Gen Comp Endocrinol 51, 263-271

Zar JH (1978) Biostatistical Analysis, Prentice-Hall, Englewood Cliffs, NJ, USA 